\title{
Hastanede Yatan ve Beslenme Destek Ekibine Danışılan Hastalarda Malnütrisyon Durumu ve Hedeflenen Beslenme Desteği Etkinliğinin Değerlendirilmesi
}

\author{
Evaluation of Malnutrition Status and Efficacy of Targeted Nutritional Support in Hospitalized \\ Patients Consulted to Nutrition Support Team
}

\author{
Betül Gülşen-Atalay¹, Simge Akyel², Suat Özer Öner ${ }^{3}$, Hasan Hakan Atalay ${ }^{4}$
}

Geliş tarihi/Received: 02.10.2018 • Kabul tarihi/Accepted: 27.03.2019

ÖZET

Amaç: Hastanede yatan ve beslenme desteği (BD) tedavisi alan hastalarda yetersiz beslenme, malnütrisyona bağll komplikasyon riskini arttırmaktadır. Bu çalışmada hastanede yatan ve BD alan hastalarda, malnütrisyon durumu ve BD tedavisinin etkinliğinin ölçülmesi amaçlanmıştır.

Bireyler ve Yöntem: Bu çalışmaya hastanede yatan, BD gereksinmesi nedeni ile beslenme destek ekibine danışılan ve izlenen 100 yetişkin ( $\geq 18$ yaş) hasta dahil edilmiştir. Hastalarda malnütrisyon durumu Nütrisyonel Risk Değerlendirme Skoru-2002 (NRS-2002) ile değerlendirilmiştir. Beslenme destek tedavisi alan hastaların hedeflenen günlük enerji ve protein gereksinmelerine ulaşma süreleri günlük vizitler ile değerlendirilmiştir. Hastalar taburcu oluncaya kadar veya hastanede ölüm görülünceye kadar izlenmiştir. Hastaların ilk değerlendirmede ve izlem süresi sonunda haftalık olarak bazı biyokimyasal parametreleri değerlendirilmiştir. Hastaların klinik sonuçları, hastanede yatış süreleri ve mortalite görülme sıklığı kayıt edilmiştir.

Bulgular: Hastanede BD ekibine danışlan hastalarda, NRS-2002 skoruna göre nütrisyonel risk altında olan hastaların sıklığ $\% 75$ ’tir. Hastalarda hedeflenen protein ve enerji gereksinmelerine ulaşma süresi sirasıyla ortalama $21.15 \pm 18.15$ gün ve 19.56 \pm 17.14 gün'dür. İzlenen hastalarda mortalite görülme sıklı̆̆ \%59'dur. Beslenme desteği tedavisine rağmen tüm hastaların BD tedavisi aldıkları son haftada serum protein değerleri (total protein ve albümin) düşmüştür ( $<<0.005$ ). Serum albümin düzeyleri ve hastanede yatış süresi arasında pozitif yönde bir ilişki bulunmuştur. Düşük serum protein değerleri mortaliteyi olumsuz yönde etkilemiştir $(\mathrm{p}<0.01)$. NRS-2002 skoru ile belirlenen nütrisyonel risk mortaliteyi ve hastanede yatış süresini etkilememiştir ( $\mathrm{p}>0.05)$.

Sonuç: Bu çalışmada, BD ekibine danışılan hastaların klinik durumunun, BD tedavisinin etkinliğini değiştirdiğini ve bu nedenle hedeflenen BD tedavisine ulaşma süresinin çok geç olduğu düşünülmektedir. Klinikte BD tedavisi alan hastaların izlemleri düzenli olarak yapılmalı ve hedef stratejiler oluşturularak izlem süreçlerinin iyileştirilmesi gerekmektedir.

Anahtar kelimeler: NRS-2002, malnütrisyon, beslenme desteği

1. İletişim/Correspondence: Toros Üniversitesi, Beslenme ve Diyetetik Bölümü, Mersin, Türkiye • E-posta: bgatalay@gmail.com

○ https://orcid.org/0000-0003-0879-5189

2. Mersin Şehir Hastanesi, Beslenme ve Diyetetik Bölümü, Mersin, Türkiye (1) https://orcid.org/0000-0001-6957-8968
3. Mersin Şehir Hastanesi, Anestezi Bölümü, Mersin, Türkiye () https://orcid.org/0000-0002-1959-0149

4. VW Medical Park Mersin Hastanesi, Mersin, Türkiye (1) https://orcid.org/0000-0002-8804-378X 


\section{ABSTRACT}

Aim: Unintentional underfeeding is common in patients receiving nutritional support (NS), and is associated with increased risk of malnutrition and complications. The aim of the study was to determine the malnutrition rate and to evaluate the efficacy of NS in hospitalized patients consulted to nutrition support team.

Subjects and Method: This study was conducted in 100 adult ( $\geq 18$ years) hospitalized patients receiving NS. Malnutrition was assessed by Nutritional Risk Screening (NRS-2002). The period to reach the targeted daily energy and protein needs of the patients receiving NS was evaluated with daily visits. Patients were followed until discharge or until death in hospital. At the first evaluation and at the end of follow-up period, patient's biochemical parameters were evaluated. The mean length of hospital stay (LOS) and the mortality rate was recorded.

Results: The frequency of patients under nutritional risk according to the NRS-2002 score was 75\% in this study. The mean time to reach the targeted amount of protein and energy requirements were $21.15 \pm 18.15$ and $19.56 \pm 17.14$ days, respectively. The mortality rate was 59\% in patients who were followed-up. Despite NS, serum protein levels (total protein, albumin) were decreased at the end of the study period $(p<0.005)$. Serum albumin levels and the LOS were positively correlated $(r=0.33$, $\mathrm{p}<0.05)$. Low serum protein levels affected the mortality negatively $(\mathrm{p}<0.01)$. The nutritional risk as determined by the NRS2002 score did not affect the mortality and length of hospital stay $(\mathrm{p}>0.05)$.

Conclusions: In this study, it was thought that the clinical status of the patients consulted to the nutrition support team changed the effectiveness of NS and therefore the time to reach the targeted NS treatment was too late. Furthermore, the reasons must be evaluated and it is necessary to use strategies in all hospitalized patients who receiving nutritional support.

Keywords: NRS-2002, malnutrition, nutritional support

\section{GíRiş}

Beslenme desteği (BD), hastanede yatan hastalarda tıbbi bakımın yaşamsal bir parçasıdır ve uygun şekilde uygulandığında yara iyileşmesini arttırabilir, yaralanmaya bağlı katabolik yanıtı azaltabilir, immün işlevi güçlendirebilir ve hastanın klinik sonuçlarını iyileştirebilir (1). Beslenme bakımının ilk adımı, hasta için uygun bireysel enerji ve/veya besin ögeleri gereksiniminin belirlenmesi ve hastaya hedeflenen tedavinin verilmesidir (1). Beslenme bütünlügünün bozulması, hastanın enerji ve protein gereksinimlerini karşılayamaması, tedavi sonucu ve komplikasyon oranından, hastanede kalış süresi ve ölüm oranına kadar hastanın tüm klinik sonucunu etkiler. Hastaneye yatan hastanin beslenme durumu, hastanın immün işlevi için çok önemli bir etmendir ve hastanin strese yanıt verme kabiliyetini etkiler. Bir hastanın yetersiz beslenmesi ve buna bağlı olarak beslenme yetersizliğinin yatış boyunca daha da kötüleşmesi, artan hastane enfeksiyonlarına, yara iyileşmesinin gecikmesine, solunum kas işlev bozukluğuna ve solunum yetmezliğine yol açabilir (2-4).
Heyland et al. (5), yoğun bakımda en az 3 gün yatan, mekanik ventilasyon desteği alan 207 yetişkin hastada yaptıkları bir çalışmada, enerji ve protein alımı daha yüksek olan hastalarda enfeksiyöz komplikasyonlarda bir azalma olduğunu göstermişlerdir. Beslenme destek tedavisi, hastanın sağlık durumundaki değişimlere göre izlenmeli, gerektiğinde değiştirilmeli ve yeterli alım sağlanmalıdır. Ancak klinik uygulamalarda, çeşitli nedenlerden dolayı hastaların yeterli alımları sağlanamamaktadır. Hastanede yatan hastalarda enteral ve parenteral beslenme desteğinin kesilmesine neden olan durumlar, teknik ve metabolik komplikasyonlar, operasyonel nedenler, gastrointestinal intolerans (diyare, bulantı-kusma, ağrı), tıbbi süreçler, rutin testlerdir (2). Yapılan çalışmalar, kritik hastaların hedeflenen beslenme gereksinimlerinin yalnızca \%40-50'sini aldığını göstermektedir (6-10). Hastanede yatan ve BD gereksinmesi nedeniyle BDE’ye danışılan hastalarda malnütrisyon yaygındır ve malnütrisyona bağlı komplikasyonlar hastanın klinik sonuçları ile ilişkili 
bir durumdur. $\mathrm{Bu}$ çalışmada, hastanede yatan ve BD alan hastalarda, nütrisyonel risk durumu ve BD tedavisinin etkinliğinin ölçülmesi amaçlanmıştır.

\section{BİREYLER VE YÖNTEM}

Mersin Şehir Hastanesi’nde yürütülen bu çalışmada, BD gereksinmesi nedeni ile beslenme destek ekibine (BDE) danışılan ve izlenen 100 ( $\geq 18$ yaş) hasta retrospektif olarak değerlendirilmiştir. Toros Üniversitesi Bilimsel Araştırma ve Yayın Kurulu Etik Kurul Kararı alındıktan sonra geriye dönük olarak bir yıllık dönemde BDE danışılan ve izlenen tüm hastalar çalışmaya dahil edilmiştir. Hastalarda malnütrisyon durumunun değerlendirilmesi, hastaneye yatıştan sonraki ilk 24 saat içinde Nütrisyonel Risk Değerlendirme Skoru-2002 (NRS-2002) kullanılarak, bu konuda eğitim almış servis hemşireleri tarafından yapılmış ve NRS-2002 skoru $\geq 3$ olan hastalar, nütrisyonel açıdan yüksek riskli hasta olarak kabul edilmiştir (11). Hastaların demografik ve klinik özellikleri, beslenme durumları, beslenmeye bağlı gelişen komplikasyonları, beslenme yolu ve dozu, günlük enerji ve protein alımları BDE tarafından günlük viziteler ile izlenmiş ve tutulan hasta kayıtları geriye dönük olarak değerlendirilmiştir. Hastaların biyokimyasal bulguları ve serum proteinleri (total protein ve albümin), konsültasyon istemi ile ilk değerlendirmede ve haftalık olarak izlenmiş ancak istatistiksel analizler izlem sonu bulgular üzerinden yapılmıştır. Hastalar taburcu oluncaya kadar veya hastanede ölüm görülünceye kadar izlenmiştir. Hastaların beslenme desteği tedavisi ile ilgili bulguları, hedeflenen protein ve enerji gereksinmelerine ulaşma süreleri, hastanede yatış süreleri ve mortalite oranları kayıtlardan elde edilerek değerlendirilmiştir. Bu çalışma için Toros Üniversitesi Bilimsel Araştırma ve Yayın Kurulu Etiği Etik Kurulu 02/04 sayılı ve 19.11.2018 tarihli “Etik Kurul Onayı” alınmıştır.

Hastaların günlük enerji gereksinmeleri pratik formül kullanılarak hesaplanmıştır (20-30 kkal/kg- vücut ağırlı̆̆ı) (12). Vücut ağırlığı normalin altında olan hastalarda, enerji hesabı >25-30 kkal/kg-vücut ağırlığı olarak hesaplanmıştır (12). Obez hastalar için (beden kütle indeksi [BKİ] $\geq 30 \mathrm{~kg} / \mathrm{m}^{2}$ ) enerji gereksinimi hesaplanırken, ideal vücut ağırlığı kullanılmıştır (13): Ayarlanmış vücut ağırlığ $=$ [IBW + (ABW - IBW x 0.25) $]$ IBW=ideal vücut ağırlığı, ABW=gerçek vücut ağırlığı

$\checkmark$ Erkek: IBW=1.54 cm için $48.2 \mathrm{~kg}+$ her $2.54 \mathrm{~cm}$ için $2.7 \mathrm{~kg}$

$\checkmark$ Kadın: IBW= $1.54 \mathrm{~cm}$ için $45.4 \mathrm{~kg}+$ her $2.54 \mathrm{~cm}$ için $2.3 \mathrm{~kg}$

Günlük hedeflenen protein gereksinmesi 1.2-1.5 $\mathrm{g} / \mathrm{kg}$ olarak hesaplanmıştır. Hedeflenen protein gereksinmesi hastanın klinik özelliklerine göre yeniden düzenlenmiştir.

Tüm hastalarda beslenme yolu olarak mümkünse enteral beslenme tedavisi (standart, hastalığa özel veya immünonütrisyon ürünleri ile) uygulanmıştır. Enteral beslenme tedavisi alan hastalarda, BDE diyetisyeni tarafından önerilen uygun ürün 20 $\mathrm{mL} / \mathrm{saat}$ hızla başlanmış, hastanın tolerasyonuna göre 4-6 saatte bir artırılarak, gereken en yüksek hedef doza çıkılmıştır. Beslenme destek ekibi rutin uygulamalarına göre hastaların günlük reziduel volümleri 6 saatte bir ölçülmüştür. Gastrik rezidüel volüm saatlik infüzyon boyunca iki kereden fazla veya 150 mL'nin üzerinde ise bir önceki doza dönülmüş ve bu reziduel volüm olarak kabul edilmiştir (14). Enteral nütrisyon tedavisine bağlı sindirim ve emilim komplikasyonları (bulantı, kusma, abdominal distansiyon ve diyare) her hasta için her vizitede kayıt altına alınan veriler ile değerlendirilmiştir. Enteral beslenme tedavisinin verilemediği ve/veya enerji ve besin ögeleri gereksinmesini karşılayamadığı durumlarda parenteral beslenme desteği tedavisine başlanmıştır. Parenteral beslenme tedavisi, üçü bir arada hazır solüsyonlar ile devamlı infüzyon şeklinde verilmiştir. İzlenen hastalarda kan glukoz düzeyi $<150 \mathrm{mg} / \mathrm{dL}$ olarak hedeflenmiş ve bu hedefi geçen hastalarda hızlı insülin infüzyonu kullanılmıştır. 


\section{Verilerin İstatistiksel Değerlendirmesi}

Çalışmada elde edilen veriler, SPSS 15.0 paket programı ile değerlendirilmiştir. Nitel ve nicel değişkenler için uygun betimsel değerler verilmiştir. Nitel değişkenler, sayı (S) ve yüzde (\%) olarak, nicel değişkenler ise ortalama ve standart sapma $(\overline{\mathrm{X}} \pm \mathrm{SS})$ olarak ifade edilmiştir. Değişkenlerin normal dağılıma uygunluğu Kolmogorov-Smirnov testi ile değerlendirilmiştir. Grupların varyanslarının homojenliği ise Levene testi ile incelenmiştir. Bağımsız iki grup arasında, sürekli değişkenler için iki ortalama arasındaki fark testi (Student-t testi veya non-parametrik test), bağımlı iki grup ve sürekli değişkenler için non-parametrik Wilcoxon testi, 3 ve üzerindeki gruplarda, nonparametrik Kruskall-Wallis analizi ve oranlar için kikare $\left(\chi^{2}\right)$ testi kullanılmıştır. $p<0.05$ değeri istatistiksel olarak anlamlı kabul edilmiştir.

\section{BULGULAR}

$\mathrm{Bu}$ çalışmada, NRS-2002 skoruna göre beslenme durumu yüksek riskli hasta oranı \%75’tir. Hastaların demografik ve klinik özellikleri Tablo 1'de gösterilmiştir. Hastaların büyük bir kısmı yoğun bakım ünitesinde tedavi almıştır. Hastaların \%19'u oral beslenme desteği, \%2'si oral beslenme desteğine ek parenteral beslenme desteği, \%59'u enteral beslenme desteği, \%18'i parenteral beslenme desteği ve $\% 2$ 'si kombine beslenme desteği tedavisi (enteral ve parenteral beslenme) almıştır. Hastaların \%51'i hedeflenen beslenme desteği tedavisine ulaşmıştır. Hastaların \%49'unda beslenme desteği hedeflerine ulaşılamamıştır. Bu hastalardan altısı izlem sırasında başka bir hastaneye nakil edilmiş, 43 hastada ise ölüm görülmüştür.

Hastalarda beslenme desteğine ara verilmesine veya kesilmesine neden olan komplikasyonların görülme oranı \%29 ve en sık görülen komplikasyonlar gastrointestinal ve hastanın klinik durumuna bağlı komplikasyonlardır. İzlenen hastalarda mortalite görülme oranı \%59'dur (Tablo 2). Beslenme durumu yüksek riskli olan hastaların serum protein değerleri, hastanede yatış süreleri ortalaması ve mortalite
Tablo 1. Demografik ve klinik bulgular

\begin{tabular}{|c|c|}
\hline Değişken & Değer \\
\hline Yaş (yıl), (ortanca, en düşük-en yüksek), yıl & $67.00(18-101)$ \\
\hline Yatış süresi (ortanca, en düşük-en yüksek), gün & $36.5(3-301)$ \\
\hline Erkek: Kadın (\%) & $59: 41$ \\
\hline \multicolumn{2}{|l|}{ Beden kütle indeksi $(\overline{\mathrm{X}} \pm \mathrm{S}), \mathrm{kg} / \mathrm{m}^{2}$} \\
\hline Yaş < 70 yll $(n=57)$ & $26.07 \pm 5.96$ \\
\hline Yaş $\geq 70$ yıl $(n=43)$ & $25.51 \pm 6.15$ \\
\hline \multicolumn{2}{|l|}{ Beden kütle indeksi, \% } \\
\hline$<18.5 \mathrm{~kg} / \mathrm{m}^{2}$ & 7.0 \\
\hline $18.5-<20 \mathrm{~kg} / \mathrm{m}^{2}$ & 2.0 \\
\hline $20.0-<22 \mathrm{~kg} / \mathrm{m}^{2}$ & 15.0 \\
\hline $22.0-<30 \mathrm{~kg} / \mathrm{m}^{2}$ & 56.0 \\
\hline$\geq 30.0 \mathrm{~kg} / \mathrm{m}^{2}$ & 20.0 \\
\hline Yoğun bakımda izlenen hastalar (\%) & 94.0 \\
\hline \multicolumn{2}{|l|}{ Bilinç durumu (\%) } \\
\hline Açık & 2.0 \\
\hline Kapalı & 88.0 \\
\hline Konfüze & 10.0 \\
\hline Entübe hastalar (\%) & 65.0 \\
\hline Mekanik ventilasyon desteği alan hastalar (\%) & 73.0 \\
\hline Yüksek riskli hasta oranı (NRS-2002) (\%) & 75.0 \\
\hline \multicolumn{2}{|l|}{ Yatış sırasındaki tanı (\%) } \\
\hline Nörolojik hastalıklar & 20.0 \\
\hline Cerrahi hastalıklar & 12.0 \\
\hline Dahili hastalıklar & 68.0 \\
\hline \multicolumn{2}{|l|}{ Ko-morbid hastalıklar (\%) } \\
\hline Diabetes mellitus & 15.0 \\
\hline Hipertansiyon & 4.0 \\
\hline Kalp yetmezliği & 3.0 \\
\hline Kronik obstruktif akciğer hastalığı & 4.0 \\
\hline Alzheimer & 3.0 \\
\hline Akut böbrek yetmezliği & 3.0 \\
\hline Kanser & 1.0 \\
\hline
\end{tabular}

oranları riskli olmayan grup ile karşılaştırıldığında istatistiksel olarak anlamlı bir fark görülmemiştir ( $p>0.05)$.

Hedeflerine ulaşılan hastalarda hedeflenen protein ve enerji gereksinmelerine ulaşma süresi sırasıyla ortalama $21.15 \pm 18.15$ gün ve $19.56 \pm 17.14$ gün’dür. Hedeflenen protein ve enerji gereksinimlerine ulaşma sürelerinin ortalaması, hastaların aldıkları beslenme yoluna göre farklılık göstermemiştir ( $p>0.05)$. Ancak hedefe ulaşılan hastaların aldıkları beslenme desteği 
Tablo 2. Hastaların beslenme desteği değerlendirme sonuçları

\begin{tabular}{|c|c|}
\hline Değişken & $\%$ \\
\hline \multicolumn{2}{|l|}{ Beslenme desteği alma durumu (\%) } \\
\hline Enteral beslenme desteği & 59.0 \\
\hline Enteral ve parenteral beslenme desteği & 2.0 \\
\hline Oral ve parenteral beslenme desteği & 2.0 \\
\hline Parenteral beslenme desteği & 18.0 \\
\hline Oral beslenme desteği & 19.0 \\
\hline $\begin{array}{l}\text { Beslenme desteği tedavisinde enteral ürün } \\
\text { kullanımı (\%) }\end{array}$ & 73.0 \\
\hline Diyabetik enteral ürün & 26.0 \\
\hline $\begin{array}{l}\text { Gastrointestinal sistem hastalıklarına özgü } \\
\text { enteral ürün }\end{array}$ & 2.0 \\
\hline İmmünonütrisyon ürünü & 14.0 \\
\hline Posalı ürün & 24.0 \\
\hline Yüksek enerjili ürün & 7.0 \\
\hline $\begin{array}{l}\text { Beslenme desteği tedavisinde parenteral ürün } \\
\text { kullanımı }\end{array}$ & 27.0 \\
\hline Soya yağı eklenmiş & 6.0 \\
\hline Zeytinyağ 1 eklenmiş & 15.0 \\
\hline Orta ve uzun zincirli yağ asidi eklenmiş & 2.0 \\
\hline $\begin{array}{l}\text { Kombine enteral (diyabetik) ve parenteral } \\
\text { destek (zeytinyağı eklenmiş) }\end{array}$ & 4.0 \\
\hline \multicolumn{2}{|l|}{ Hedeflenen beslenme desteği alımı (\%) } \\
\hline Ulaşılan & 51 \\
\hline Ulaşılamayan & 49 \\
\hline \multicolumn{2}{|l|}{$\begin{array}{l}\text { Beslenme destek tedavisi alan hastalarda } \\
\text { görülen komplikasyonlar* (\%) }\end{array}$} \\
\hline Gastrointestinal & 11 \\
\hline Metabolik & 2 \\
\hline Teknik & 4 \\
\hline $\begin{array}{l}\text { Beslenme desteğinin kesilmesine neden olan } \\
\text { hastalığa bağlı durumlar (\%)** }\end{array}$ & 12 \\
\hline
\end{tabular}

yolu ile ulaşılmayan hastaların aldıkları beslenme desteği yolu arasında istatistiksel olarak anlamlı bir fark bulunmuştur ( $\mathrm{p}=0.006)$ (Tablo 3).

Çalışma sonunda beslenme desteğine rağmen, tüm hastaların serum protein değerlerinde bir azalma görülmüştür ( $\mathrm{p}<0.005)$ (Tablo 4). Hastaların izlem sonu serum albümin değerleri ve hastanede yatış süreleri ile pozitif yönde bir ilişki saptanmıştır $(r=0.33$, $\mathrm{p}<0.05)$ (Şekil 1). Düşük serum albümin ve total protein değerleri mortalite oranını anlamlı olarak etkilemiştir $(\mathrm{p}<0.01)$ (Şekil 2).

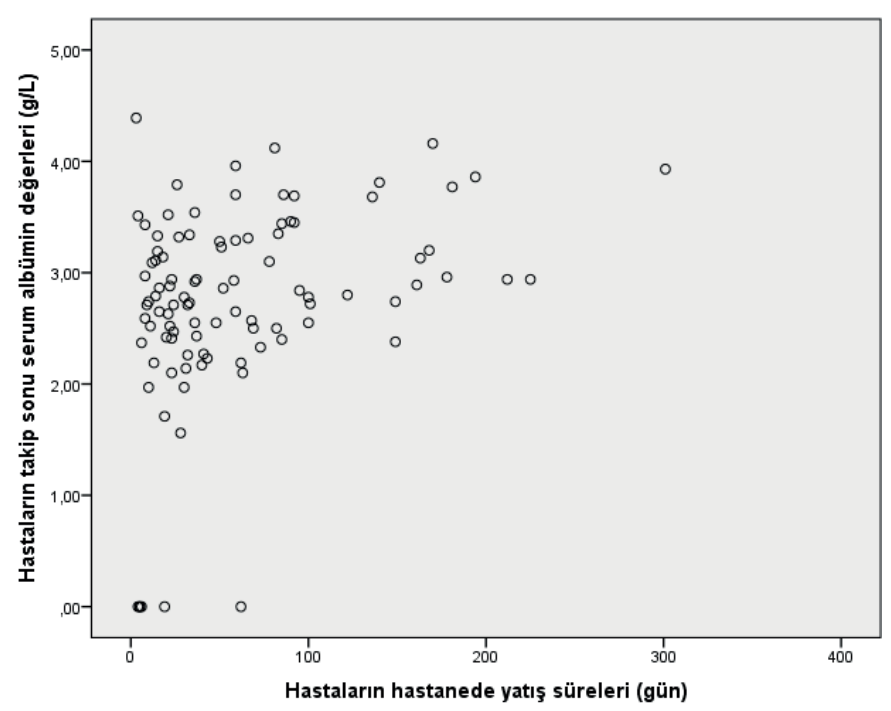

Şekil 1. Hastaların izlem sonu serum albümin değerleri ve hastanede yatış sürelerinin non-parametrik Spearman korelasyon analizi ile değerlendirilmesi

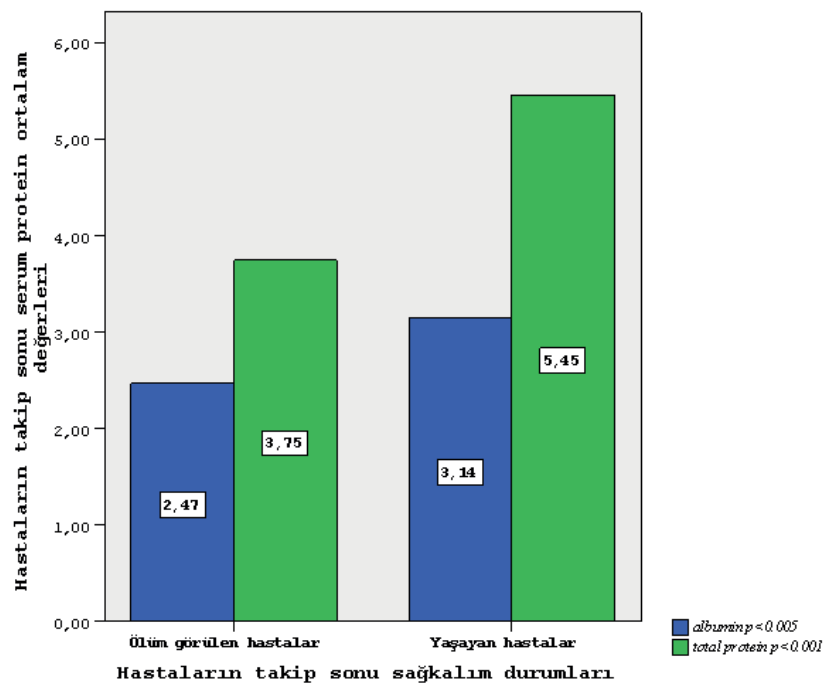

Şekil 2. Hastanede hastaların izlem süresinin sonunda sağkalım durumları ve serum protein değerleri 
Tablo 3. Hastaların aldıkları beslenme destek tedavisi yoluna göre hedefe ulaşma durumları ve hedefe ulaşılan günlere göre değerlendirilmesi

\begin{tabular}{|c|c|c|c|}
\hline & $\begin{array}{l}\text { Hedefe ulaşılan } \\
\text { hasta }(n=51)\end{array}$ & $\begin{array}{c}\text { Hedefe } \\
\text { ulaşılamayan hasta } \\
(n=49)\end{array}$ & $\mathbf{p}$ \\
\hline \multicolumn{4}{|l|}{ Beslenme desteği yolu (S, \%) } \\
\hline Enteral beslenme & $35(59.3)$ & $24(40.7)$ & \multirow{4}{*}{$0.006^{*}$} \\
\hline Enteral beslenme+parenteral destek & $1(25.0)$ & $3(75.0)$ & \\
\hline Parenteral beslenme & $3(16.7)$ & 15(83.3) & \\
\hline Oral beslenme desteği & $12(63.2)$ & $7(36.8)$ & \\
\hline Beslenme desteğine ulaşma süresi, gün & Protein $(\overline{\mathrm{X}} \pm \mathrm{S})$ & Enerji $(\overline{\mathrm{X}} \pm \mathrm{S})$ & $\mathbf{p}$ \\
\hline Enteral beslenme & $24.55 \pm 20.44$ & $23.94 \pm 20.17$ & \multirow{4}{*}{0.419} \\
\hline Enteral beslenme+parenteral destek & $18.00 \pm 00.00$ & $18.00 \pm 00.00$ & \\
\hline Parenteral beslenme & $27.00 \pm 25.23$ & $26.66 \pm 24.78$ & \\
\hline Oral beslenme desteği & $15.58 \pm 20.86$ & $15.58 \pm 20.86$ & \\
\hline Tüm hastalarda hedeflenen beslenme desteğine ulaşma süresi, gün $\left(\bar{X}_{ \pm} S\right)$ & $21.15 \pm 18.15$ & $19.56 \pm 17.14$ & \\
\hline
\end{tabular}

${ }^{*}$ Kikare analizi, $p<0.05$

Tablo 4. Beslenme destek tedavisi alan hastaların izlem öncesi ve sonrası serum toplam protein ve albümin düzeylerinin ortalaması

\begin{tabular}{lcccc}
\hline & \multicolumn{4}{c}{ Serum protein değerleri $\left(\overline{\mathbf{X}}_{ \pm} \mathbf{S S}\right)$} \\
& Total protein $(\mathbf{g} / \mathbf{L})$ & $\mathbf{p}$ & Albümin $(\mathbf{g} / \mathbf{L})$ & $\mathbf{p}$ \\
\hline $\begin{array}{l}\text { Tüm hastalarda ilk değerlendirme } \\
\text { Tüm hastalarda son değerlendirme }\end{array}$ & $4.97 \pm 2.75$ & $0.005^{*}$ & $3.24 \pm 1.05$ & $0.001^{*}$ \\
$\quad$ Yüksek riskli olmayan hasta grubu & $4.33 \pm 2.79$ & & $2.73 \pm 0.89$ & \\
$\quad$ & & & & \\
$\quad$ Illk değerlendirme & $5.76 \pm 2.20$ & 0.135 & $3.52 \pm 0.79$ & $0.009^{*}$ \\
$\quad$ Son değerlendirme & $5.33 \pm 2.21$ & & $2.90 \pm 0.58$ & \\
$\quad$ Yüksek riskli hasta grubu & & & & $0.001^{*}$ \\
$\quad$ İlk değerlendirme & $4.68 \pm 2.89$ & $0.02^{*}$ & $3.14 \pm 1.12$ & \\
$\quad$ Son değerlendirme & $3.95 \pm 2.91$ & & $2.65 \pm 0.97$ & \\
\hline
\end{tabular}

Non-parametrik analiz, Wilcoxon ranks test, ${ }^{*} p<0.05$

\section{TARTIŞMA}

Sağllk sorunu nedeniyle hastaneye başvuran hastada, yetersiz beslenmeye veya hastalığa bağlı malnütrisyonun varlığı tedavinin başarısını olumsuz yönde etkiler. Malnütrisyon, iyileşmeyi geciktirip hastanede kalış süresini uzatabilir, enfeksiyona karşı duyarlılığı artırır, yaşam kalitesini düşürür ve çoğu hastada ölüm riskini artırır (15). Studley et al. (16), 1936 yılında, peptik ülser ameliyatı geçiren hastalardaki mortalite nedeninin preoperatif vücut ağırlığı kaybının miktarına bağlı olduğunu bildirmiş ve daha sonraki birçok çalışma sonuçları bu araştırmayla paralel bulgular göstermiş ve bu bilgi neredeyse klasikleşmiştir $(15,16)$.
Türkiye'deki çeşitli merkezlerde yapılan çalışmalarda, hastaneye yatan hastalarda malnütrisyon oranının \%11-63 arasında olduğu bildirilmiştir (17-20). Hastaneye yattıktan sonra iştah azalması, anksiyete, ortam ve yemek zamanında değişiklikler, hastane yemeklerine ve diyetlerine uyum sağlayamama, primer hastalık varlığı, tetkik amacı ile aç kalma gibi nedenler, hastaların beslenme durumunu bozan etmenler olarak bildirilmiştir. Ayrıca hastaların vücut ağırlığı ve boy uzunluğunun ölçülememesi, çalışan personelin rotasyonu, sorumluluğun birçok kişide olması, besin tüketim izleminin iyi yapılmaması, yaralanma ve sepsis gibi nedenlerle 
artan besin ögesi gereksiniminin fark edilememesi, post-operatif dönemde uzun süreli glukoz sodyum solüsyonlarının kullanılması, uygun beslenme desteğinin geciktirilmesi de hastayı malnütrisyona götüren etmenlerdir (21). Bu nedenle hastanın yakından izlenerek gerektiği anda beslenme desteği tedavisi sağlanması esastır.

Hastanede yatan ve beslenme desteğine başlanması amacıyla BDE’ye danışılan hastalarda nütrisyonel durumun ve beslenme desteğinin klinik sonuçlara olan etkisinin değerlendirildiği bu araştırmada, hastaların büyük çoğunluğunun nütrisyonel açıdan risk altında olduğu, hastalarda hedeflenen enerji ve protein gereksinimlerine ulaşma süresinin geç olduğu belirlenmiştir. Beslenme destek ekibi çalışma protokolüne göre, hastanın beslenme desteği için her zaman ilk tercih oral destek ve/veya enteral beslenme olmuş ancak oral-enteral yoldan beslenme desteği sağlanamayacaksa gecikmeden beslenme desteği parenteral olarak önerilmiştir. Özellikle kritik hastalıklarda beslenme desteğinin ne zaman başlanacağı (erken/geç), hangi miktarda verileceği, içeriğinin nasıl olacağı gibi birçok konuda halen çalışmalar devam etmekle birlikte uluslararası kılavuz önerileri klinik uygulamalara rehberlik etmektedir $(22,23)$.Kanada yoğun bakım klinikuygulama kılavuzu, yoğun bakımda yatan hastalarda hemodinamik stabilizasyon sağlandıktan sonra 24-48 saat içinde beslenmeye başlanmasını ve hedef enerji alımına 48-72 saatte ulaşılmasını önermektedir (22). Avrupa Klinik Beslenme ve Metabolizma Derneği (European Society for Clinical Nutrition and Metabolism [ESPEN]) kılavuzu da, yoğun bakımda yatan ve 3 gün içinde ağızdan tam doz nütrisyona başlanması beklenmeyen tüm hastalarda ilk 24 saat içinde enteral beslenme başlanmasını önermektedir (23). Çalışmada tanısal veya tıbbi tedavi amaçlı süreçler nedeni ile beslenme desteğine ara verilmesi veya kesilmesi, yetersiz alıma neden olan önemli nedenlerden bir tanesidir ve bu durumun BDE tarafindan izlenmesi oldukça zordur. Diğer sık görülen nedenler beslenme desteğine bağlı hem enteral hem parenteral beslenme desteği alan hastalarda komplikasyonların (enteral beslenen hastalarda yüksek gastrik rezidüel volüm, tüple ilgili mekanik komplikasyonlar ve parenteral beslenen hastalarda metabolik veya septik komplikasyonlar gibi) görülebilmesidir (24). Bu çalışmada hedeflenen enerji ve protein gereksinimlerine ulaşılamamasına yol açan önemli etmenlerden biri enteral beslenen hastalarda gastrointestinal komplikasyonların gelişmesi ve beslenmenin kesintiye uğramasıdır. Yapılan birçok çalışmada, intolerans bulguları olmaksızın rezidü gerekçesi ile beslenmenin kesildiği saptanmıştır (25-27). Bu çalışmada gastrik rezidüel volüm saatlik infüzyon boyunca iki kereden fazla veya 150 mL'nin üzerinde ise bir önceki doza dönülmüş ve bu reziduel volüm olarak kabul edilmiştir. Uluslararası kılavuzların önerilerine göre intolerans bulguları olmaksızın 500 mL'nin altındaki rezidü miktarlarının kesinti için gerekçe olmaması gerektiği ifade edilmektedir (22,23). McClave et al. (28), gastrik rezidüel volüm miktarı 250-500 mL olan hastalar ve 50-150 mL olan hastaları karşılaştırmıştır. Sonuçta rezidüel miktarları yüksek olan hastalarda aspirasyon, aspirasyon pnömonisi ve regürjitasyonun daha fazla olmadığı görülmüştür. Araştırmacılar rezidü miktarının aspirasyon pnomonisi için bir risk etmeni olmadığı sonucuna varmışlardır (28).

Bu çalışmada, beslenme desteğinin kesilmesi veya ara verilmesine neden olan, hastanın klinik durumuna bağlı komplikasyonlar da yüksek oranda gelişmiştir. Hastaların büyük çoğunluğunun yoğun bakımda izlenmesi ve genel durumlarındaki kötü seyrin, yoğun bakımda izlenen hastalarda hipotansiyon gelişmesi, hastanın solunum sıkıntısı olması, izlem süresince gelişen elektrolit dengesizlikleri gibi durumların da buna etki ettiği görülmüştür. Akbay ve arkadaşları (29), hastanede enteral beslenme desteği veya kombine beslenme desteği tedavisi alan hastaların enerji alımlarını değerlendirdikleri çalışmada, BD alan hastalarda izlenen günler içinde yetersiz beslenme desteği aldıkları gün oranını hemodinamik intolerans nedeniyle \%18.8 olarak saptamışlardır. 
$\mathrm{Bu}$ çalışmada beslenme hedeflerine ulaşılamaması veya geç ulaşılmasındaki esas sorunun, enteral beslenme desteği ile yeterli enerji ve protein alamayan hastalara, parenteral destek tedavisine başlama süresinin gecikmesi veya gereksinmesini kombine tedavi ile karşllayamayan hastalara santral kateter açlarak total parenteral beslenme kararının gecikmesi olduğu düşünülmektedir. ESPEN ile Amerikan Parenteral ve Enteral Beslenme Derneği (American Society for Parenteral and Enteral Nutrition [A.S.P.E.N]), enteral beslenme ile yeterli enerji ve protein alamayan hastalara ek parenteral beslenme desteği başlanmasını önermektedir (30,31). Avrupa Klinik Beslenme ve Metabolizma Derneği rehberi hedefe ulaşllamayan hastada üçüncü günde ek parenteral destek tedavisine başlanmasını önermekte iken, A.S.P.E.N rehberi, enerji ve protein gereksinmesinin \%60'ından fazlasını karşılayamayan hastada 7-10. günlerde ek parenteral beslenme desteğini önermektedir. Avrupa Yoğun Bakım Derneği [European Society of Intensive Care Medicine (ESICM)]'nin son yayınladığı klinik uygulama kılavuzları, kritik hastaların çoğunda erken enteral beslenmenin kullanılmasını savunmakta ve enteral beslenmenin geciktirilmesi gerektiğinde spesifik klinik durumları tanımlamaktadır. Ancak bu kllavuzda, enteral beslenmenin yetersiz veya kontraendike olduğu hastaların beslenme desteği tedavisinin nasıl olması gerektiği spesifik olarak ele alınmamıştır (32).

Çalışmada beslenme desteği nedeniyle BDE’ye danışılan hastalarda nütrisyonel risk altındaki hastaların oranlarının yüksek olduğu ve beslenme desteğine rağmen tüm hastalarda serum protein düzeylerinin azaldığı bulunmuştur. Beslenme destek tedavisinin etkinliğinin sağlanabilmesi için, hastanın hastaneye yattığı ilk 24 saat içinde beslenme durumunun değerlendirilmesi ve malnütrisyon veya beslenme açısından yüksek riskli olarak değerlendirilen tüm hastaların BDE’ye danışılmalıdır. Hastaların uygun beslenme desteği tedavisi ve düzenli olarak beslenme durumunun saptanması ile düzenli izlem yapılmalıdır. Tedavi süreci boyunca karşılaşılan beslenme kesintileri değerlendirilmeli, hedef beslenme tedavisine ulaşabilmek için ek destekl ürünleri hastanın primer hekimi ve BDE ile birlikte değerlendirilmelidir.

$\mathrm{Bu}$ çalışmanın en önemli kısıtlılı̆̆ı, çalışmanın retrospektif olarak yürütülmesi nedeniyle hastaların beslenme tedavisi süreçlerindeki değişikliklerin ayrıntılı olarak saptanamaması, hedefe ulaşılamayan hastalarda, hasta bazında değerlendirme yapılamamış olmasıdır. Bu konuda yapılacak daha çok hasta katılımlı randomize kontrollü prospektif çalışmalara gerek vardır.

Çıkar çatışması - Conflict of interest: Yazarlar çıkar çatışması olmadığını beyan ederler. - The authors declare that they have no conflict of interest.

\section{KAYNAKLAR}

1. Coughlin KL, Austhof SI, Hamilton C. (İnanç N, Çiçek B, çeviri). Beslenme Desteği: Endikasyon ve Etkinlik. Skipper A. (İnanç N, Besler T, çeviri editörleri) Diyetisyen El Kitabı: Enteral ve Parenteral Nütrisyon. 2. Baskı. İstanbul: Nobel Tıp Kitabevi; 2014. s. 22-45.

2. Lupián-Angulo AI, Ortíz-Reyes LA, Castillo-Martínez L, Serralde-Zúñiga AE. Enteral nutritional support in nonICU hospitalized patients: current practice in Mexico. Asia Pac J Clin Nutr. 2017;26:586-90.

3. Heyland DK, Cahill N, Day AG. Optimal amount of calories for critically ill patients: depends on how you slice the cake! Crit Care Med. 2011;39:2619-26.

4. McClave SA, Lowen CC, Kleber MJ, Nicholson JF, Jimmerson SC, McConnell JW, et al. Are patients fed appropriately according to their caloric requirements? JPEN. 1998;22:375-81.

5. Heyland DK, Stephens K, Day A, McClave SA. The success of enteral nutrition and ICU-acquired infections: a multicenter observational study. Clin Nutr. 2011;30:148 $-55$.

6. Barr J, Hecht M, Flavin KE, Khorana A, Gould MK. Outcomes in critically ill patients before and after the implementation of an evidence-based nutritional management protocol. Chest. 2004;125:1446 -57.

7. Binnekade JM, Tepaske R, Bruynzeel P, Mathus-Vliegen EM, de Hann RJ. Daily enteral feeding practice on the ICU: Attainment of goals and interfering factors. Crit Care. 2005;9:R218-R225. 
8. De Jonghe B, Appere-De-Vechi C, Fournier M, Tran B, Merrer J, Melchior JC, et al. A prospective survey of nutritional support practices in intensive care unit patients: What is prescribed? What is delivered? Crit Care Med. 2001;29:8-12.

9. Heyland DK, Schroter-Noppe D, Drover JW, Jain M, Keefe L, Dhaliwal R, et al. Nutrition support in the critical care setting: Current practice in Canadian ICUsOpportunities for improvement? JPEN. 2003;27:74 - 83.

10. McClave SA, Sexton LK, Spain DA, Adams JL, Owens NA, Sullins $\mathrm{MB}$, et al. Enteral tube feeding in the intensivecare unit: Factors impeding adequate delivery. Crit Care Med. 1999;27:1252-6.

11. Kondrup J, Allison SP, Elia M, Vellas B, Plauth M. Educational and Clinical Practice Committee, European Society of Parenteral and Enteral Nutrition (ESPEN). ESPEN guidelines for nutrition screening 2002. Clin Nutr. 2003;22:415-21.

12. Kreymann KG, Berger MM, Deutz NE, Hiesmayr M, Jolliet P, Kazandjiev G, et al. ESPEN Guidelines on Enteral Nutrition: Intensive care. Clin Nutr. 2006;25(2):210-23.

13. Cutts ME, Dowdy RP, Ellersieck MR, Edes TE. Predicting energy needs in ventilator-dependent critically ill patients: effect of adjusting weight for edema or adiposity. Am J Clin Nutr. 1997;66(5):1250-6.

14. Taylor BE, McClave SA, Martindale RG, Warren MM, Johnson DR, Braunschweig C, et al. Guidelines for the Provision and Assessment of Nutrition Support Therapy in the Adult Critically Ill Patient: Society of Critical Care Medicine (SCCM) and American Society for Parenteral and Enteral Nutrition (A.S.P.E.N.). Crit Care Med. 2016;44(2):390-438.

15. Gündoğdu H. Malnütrisyon. İç Hastalıkları Dergisi. 2010;17:189-202.

16. Studley HO. Percentage of weight loss: a basic indicator of surgical risk in patients with chronic peptic ulcer. JAMA. 1936;106:458-60.

17. Gündoğdu H, Tunçyürek P, Gülgör N, Petriçli P, Avşar B. Cerrahide nütrisyon durumunun değerlendirilmesi eğitimi. Ulusal Cerrahi Dergisi. 2003;19:128-32.

18. Sungurtekin H, Sungurtekin U, Balci C, Zencir M, Erdem E. The influence of nutritional status on complications after major intraabdominal surgery. J Am Coll Nutr. 2004;23: 227-32.

19. Nursal TZ, Noyan T, Atalay BG, Köz N, Karakayali H. Simple two-part tool for screening of malnutrition. Nutrition. 2005; 21:659-65.

20. Kuzu MA, Terzioğlu H, Genç V, Erkek AB, Ozban $\mathrm{M}$, Sonyürek $\mathrm{P}$, et al. Preoperative nutritional risk assessment in predicting postoperative outcome in patients undergoing major surgery. World J Surg. 2006;30:378-90.

21. Mercanlıgil S, Keçecioğlu S. Enteral ve Parenteral Beslenme. Baysal A, Aksoy M, Besler T, Bozkurt N, Keçecioğlu S, Mercanlıgil S ve arkadaşları, editörler. Diyet El Kitabı. 8. Baskı. Hatiboğlu Yayınları:Ankara. 2014. s. 519-562.

22. Heyland DK, Dhaliwal R, Drover JW, Gramlich L, Dodek P, Canadian Critical Care Clinical Practice Guidelines C. Canadian Clinical Practice Guidelines for Nutrition Support in mechanically ventilated, critically ill adult patients. JPEN. 2003;27(5):355-73.

23. Singer P, Blaser AR, Berger MM, Alhazzani W, Calder PC, Casaer MP, et al. ESPEN guideline on clinical nutrition in the intensive care unit. Clin Nutr. 2019;38(1):48-79.

24. Sehgal IS, Singh N. Nutritional Management in the Intensive Care Unit. World Clin Pulm Crit Care Med. 2015;4(2):138-56.

25. Elke G, Felbinger TW, Heyland DK. Gastric residual volume in critically ill patients: a dead marker or still alive? Nutr Clin Pract. 2015;30:59-71.

26. Mallampallı A, McClave SA, Snider HL. Defining tolerance to enteral feeding in the intensive care unit. Clin Nutr. 2000;19:213-5.

27. Edwards SJ, Metheny NA. Measurement of gastric residual volume: State of the science. Medsurg Nursing. 2000;9:125-8.

28. McClave SA, Lukan JK, Stefater JA, Lowen CC, Looney SW, Matheson PJ, et al. Poor validity of residual volumes as a marker for risk of aspiration in critically ill patients. Crit Care Med. 2005;33(2):324-30.

29. Akbay H, Gömceli IM, Yolcular BO, Cekin AH. Importance of target calorie intake in hospitalized patients. Turk J Gastroenterol. 2017;28:289-97.

30. Singer P, Berger MM, Van den Berghe G, Biolo G, Calder P, Forbes A, et al. ESPEN guidelines on parenteral nutrition: Intensive care. Clin Nutr. 2009;28:387-400.

31. McClave SA, Taylor BE, Martindale RG, Warren MM, Johnson DR, Braunschweig C, et al. Guidelines for the provision and assessment of nutrition support therapy in the adult critically ill patient: Society of Critical Care Medicine (SCCM) and American Society for Parenteral and Enteral Nutrition (A.S.P.E.N.). JPEN. 2016;40:159211.

32. Reintam Blaser A, Starkopf J, Alhazzani W, Berger MM, Casaer MP, Deane AM, et al. Early enteral nutrition in critically ill patients: ESICM clinical practice guidelines. Intensive Care Med. 2017;43:380-98. 